\title{
Mosque as a Platform to Address the Issues of the Anti-Hadith in Malaysia
}

\author{
Mohd Al'lkhsan Ghazali' ${ }^{*}$ \\ Muhammad Fathi Yusof ${ }^{2}$ \\ Siti Salwa Md. Sawari ${ }^{3}$ \\ Faisal Ahmad Shah ${ }^{4}$ \\ ${ }^{13}$ Faculty of Islamic Civilization, Universiti Teknologi Malaysia \\ 2 UTM Razak School, Universiti Teknologi Malaysia \\ ${ }^{4}$ Academy of Islamic Studies, Universiti Malaya; 'Email: ${ }^{1}$ alikhsan@ic.utm.my
}

\section{Doi:10.5901/mjss.2016.v7n2s1p553}

\begin{abstract}
The anti-hadith phenomenon in Malaysia has urged the authorities to implement varieties of grassroots actions to combat its spread. Various parties have come together to address this issue, especially the religious authorities whether at the federal or state level. Besides that, mosque institutions play their roles by organizing weekly talks and lectures to overcome the antihadith movement. Therefore, this study was conducted to measure the extent to which the mosque institutions in Malaysia have successfully contributed to the eradication of the anti-hadith group among society. This study was a quantitative study in which the researcher has distributed survey questionnaires on demographic, practice and involvement with lectures in mosques and also questions related to the anti-hadith. A total of 800 people were involved in the survey. The finding based on detailed analysis has shown that those who liked to present themselves in the mosques were safe from the influence of the anti-hadith. This finding illustrates that religious teachings in mosques have managed to keep the faith of the Muslims from being misguided in terms of Islamic practices and unfavourable potential to be influenced by the anti-hadith movement less than those who did not go there. Based on this study, religious education in mosques is one of the main factors which could save the Muslims from the influence of the anti-hadith. Hence, this study suggested that all parties should enhance and diversify the religious lectures.
\end{abstract}

Keywords: Anti-Hadith Group; Mosque, Quantitative, Questionnaires.

\section{Introduction}

Hadith as the second Islamic source after the Quran has been rejected and denied by some individual and groups (Ghazali \& Md. Sawari, 2014). In Malaysia, the groups which have rejected the hadith are known as the anti-Hadith Group. They are also known by other names such as Jamaah Al-Qur'an, the group which rejected the hadith, alQur'aniyyun and so on. The existence of the anti-hadith groups in Malaysia since 1984 have been developed by intellectuals and influential people. Although these groups are officially forbidden in Malaysia by the National Fatwa Council (BAHEIS, 1995), these groups are still active in spreading their ideologies secretly (Ghazali, Md. Sawari \& Yusuf, 2015). This effort leads them to move into other doctrines which share similar ideologies in arguing Islamic values and laws. They continue to move in different ways by using all opportunities that they have.

Due to their secret movement, further actions could not be taken as no report was made. Nowadays, the arrival of modern technologies such as internet has contributed to the success of spreading the anti-hadith ideologies. This phenomenon has aroused the existence of the anti-hadith groups in Malaysia. Therefore, many parties in Malaysia who were aware of this issue have taken a lot of grassroots actions to solve the issues of the anti hadith groups in Malaysia including local authorities especially religious authorities either at the federal or state level. Besides that, drastic actions were also taken by local educational institutions and individuals who were concerned towards this issue by abolishing and preventing the anti-hadith ideologies from spreading. Moreover, mosque institutions also have played their roles by organizing weekly talks and lectures to stop the anti-hadith groups and their ideologies from spreading.

Though many actions were already taken, the anti-hadith groups are still exist in Malaysia until now. It is unclear whether all the actions taken were still unable to abolish the anti-hadith groups completely. Therefore, a detailed study was conducted to examine the extent to which the mosque institutions in Malaysia have successfully contributed to the 
eradication of the anti-hadith groups among society and whether the actions taken were ineffective to the community. Hence, this study aimed to answer the research questions.

\title{
2. Statment of Problem
}

Muslims particularly in Malaysia believe in the principles of faith and the rules of religion inherited since early ages. These rules and principles have been hold by Muslims since they came from the foundation of Islamic sources which are the Quran (Al Hafiz et, al, 2016a, 2016b) and the Sunnah of the Prophet Muhammad S.A.W (Muhaidi, Mohd Al'Ikhsan \& Siti Salwa, 2015a, 2015b). The matters of faith such as the existence of punishment after the death or the Shariah matters like covering the aurah are the matters which have been agreed upon and approved by the Muslims. There is no one who rejected these Islamic rules and principles unless those who have gone astray. Therefore, these matters are authentic, the validity descended from Allah and His Messenger S.A.W. All new things especially the one which opposes the authentic was rejected.

The anti-hadith issues began in Malaysia in 1986 with the publication of a book written by Kassim Ahmad titled 'Hadis Satu Penilaian Semula' (Hadith A Reassessment). He urged Muslims to leave the hadith that caused disunity among people and stick only to the Qur'an (BAHEIS 1995). Those involved in this teaching were known as the anti-hadith groups, who said that the task of the Prophet S.A.W. was only to bring the Qur'an to mankind. Thus, according to them, Al-Qur'an was the only one which should be followed, not more than that (Hafiz 2002).

The banned on the book of 'Hadis Satu Penilaian Semula' (Hadith A Reassessment) by the Ministry of Home Affairs on June 7, 1986 (BAHEIS 1995) and the banned on the anti-hadith movement by the National Fatwa Committee in 1995 (Abdul Hamid t.th.) did not restrict the anti-hadith activities and teachings. Now, they have a more intense and effective medium which is the internet. In addition, they also spread their teachings by writing articles in local newspapers, distributing free leaflets from house to house and putting up posters in public places (Hafiz 2002). In the current issue leaflets 'Fenomina Ajaran Sesat Di Malaysia' (Heresies Phenomenon in Malaysia), JAKIM has listed the anti-hadith teachings as one of 15 heresies that were still active in Malaysia (Jakim t.th.).

The anti-hadith groups have successfully influenced some of the Muslim thinkers in Malaysia especially the intellectuals among university lecturer, journalist, author, writer, medical doctor, doctorate in economics and so on (Abdul Hamid t.th.). Their main target was the public people who have little knowledge about Islam (Hafiz 2002). According to Selangor's Mufti (Kosmo May 18, 2006), those who were affected and became followers of the anti-hadith groups, were not only those with limited knowledge of his religion but also included those who were professionals in religion field

\section{Literature Review}

According to Dewan Dictionary (2002), 'tribe' is a group or groups and anti is a prefix which means against, oppose or disagree. The literal meaning of the hadith is new or news (al-Fairuzabadi 1987), or what is uttered by a speaker (Khalil al-Jur t.th.).

\begin{abstract}
Munkir is an isim facil (doer) from the word ankara yunkiru inkaran ( أنكر بنكر إنكار ). Denying something is ignorant while denying or rejecting the bounties is blasphemy (Khalil al-Jur t.th.), as Allah S.W.T says (Al-Qur'an, Surah al-Nahl 16:83): "They recognize the favours of Allah; then they deny them; and most of them are (creatures) ungrateful."
\end{abstract}

In Lisan al-cArab: Denying is similar with juhud which means denying in the situation where one is in consciousness (Ibn Manzur t.th.). According to Dewan Dictionary (2002), disobey or deny has three purposes, first; does not allow (claimed), deny, reject and break the rule, second; reluctant, does not comply and does not want and third; denial, rejection and neglecting the rule.

Sunnah originally means the way (al-Nawawi t.th.). Sunnah also means 'sirah' and 'regular way' whether good or bad (Ibn Manzur t.th.). The word Sunnah which means 'the way' is found in some verses in the Qur'an, one of them is the word of Allah S.W.T. (Al-Qur'an, Surah al-Nisa'4: 26):

It means:

\section{Allah does wish to make clear to you and to show you the ordinances of those before you; and (He does wish to) turn to you (in Mercy): and Allah is All-Knowing, All-Wise.}

The word Sunnah which means 'the way' is also found in some hadith of the Prophet S.A.W., one of the hadith is: 
Anyone who creates (set up) the good way (to be followed) in Islam, then he will get his reward and the reward of those who do so afterwards without the slightest decrease in their merits, and anyone who creates (set up) bad way (to be followed) in Islam, then he will get his sin and the sin of those who do so afterwards without the slightest decrease in their sins.

(Reported by Muslim)

\subsection{The History Of Sunnah Rejection}

The rejection of the hadith of Prophet Muhammad S.A.W is not new. It has been started since the time of Imam Shafie. The seeds towards the rejection of hadith have begun earlier during the time of the Prophet and his companions. During Prophet's time, an Arab Bedouin who was ignorant and misguided has met the Prophet S.A.W. He has questioned about the division of property made by the Prophet S.A.W. That property came from Yemen. The companions have described in words on the physical appearance of that man (al-Ashqar 1999): A person with the eyes inward, high cheekbones, his forehead raised, thick beard and bald with short sarong. He told the Prophet S.A.W. like a leader with extensive knowledge after the Prophet S.A.W. finished dividing the property: Fear Allah S.W.T. Then said the Prophet: "Woe to you, am I not a member of the Earth who is most eligible for fear of Allah S.W.T? When he left, the Prophet S.A.W said: Undoubtedly will come from that man, people who read the Book of Allah S.W.T. smoothly, but do not pass through their throat, they have moved out from their religion like an arrow released from its target".

Al-Hasan al-Basri narrated: When 'Imran bin Husain was sitting with his companions, a man said: Do not tell us apart from the Quran. He said: Come here, and then we approached him. 'Imran answered: What do you think if you and your friends teach the Qur'an, did you ever find in it, four rakaah zuhr prayer, four rakaah Asr prayer, three rakaah maghrib prayer through a strong reading on both? What do you think if you and your friends teach the Quran, do you find in it seven times circles around the Kaabah and seven times circles between Safa and Marwah? Then he said: $O$ my people take from us, for God's sake, if you do so you will not go astray.

According to Habeeb (2004), confusion like this also happened to Umayya ibn Khalid in which he was trying to solve all the problems by using the Qur'an alone. He has said to Abdullah ibn Umar: We found the descriptions of the five daily prayers and the prayers during the war in the Qur'an, but we did not find anything about prayers during travelling in it. Then Abdullah ibn Umar said: My nephew, Allah has sent to us Prophet Muhammad S.A.W. and we did not know anything. Surely we will do what have been done by the Prophet S.A.W.

In Sahih Bukhari and Muslim, there was a story of a woman who came to Abdullah ibn Masud r.a. as follows: A woman came to meet with a well-known companion Abdullah ibn Masud r.a then criticized him because he has insulted the women who made tattoos, women who shaved their eyebrows and women who changed their teeth to make it beautiful, women who changed Allah's creation. He said to that woman: Why can't I curse those who were cursed by the Prophet S.A.W and this was found in the Book of Allah S.W.T She said: I have read the Book of Allah S.W.T. and I did not find anything. He said: If you read it you will surely find it, don't you read the word of Allah S.W.T.: ... What the Messenger gives to you, accept it and what he forbids you, leave it. The woman said: Yes. Ibn Masud said: Verily the Prophet S.A.W. has forbidden them. The same also applied to Ayub al-Sakhtiani, when he said: When I taught hadith to a man, he has said: Tell us nothing except the Qur'an. Ayub said: Behold this man is misguided and misleading (al Khatib).

Across the time, the numbers of individual who adhered to the Qur'an solely were increasing. However, at that time, they did not represent any group and they moved individually. Generally, this ideology did not occur in all Muslim countries. It just happened in Iraq, or more specifically in Basrah. The facts to this problem were 'Imran ibn Husain and Ayub al-Sakhtiani, both lived in Basrah. The statement from Imam Shafie who has stated that most of the denials of the hadith were from Basrah reinforced this theory (al -A'zomi 1992 \& al-Siba'ie \& 1985).

After the time of Imam Shafie, issues about the rejection of the hadith or the opinions referred only to the Quran without referring to other sources of Islamic law; hadith, consensus (ijma') and analogy (qiyas) were no longer heard. Muslims have agreed to accept the Hadith as the second source of knowledge after Al-Qur'an (Habeeb 2004). There were no more individuals or groups who denied the hadith in the end of the second century or even much longer until the end of the third century. This defamation came back after the conquest of the West in the 14th century (al-A'zomi 1992).

\subsection{The Sunnah Position In The Khawarij, Muktazilah And Syiah Groups}

All Islamists use Sunnah as their source of reference. However, there was also among those who rejected the Sunnah. This refusal was not because of the basis that sunnah was not an argument. Their refusal however was due to the way it was narrated by a companion who they believed were infidels, and their hadiths were rejected as happened to firqah 
Khawarij and Syiah. The refusal also occurred because of the hadiths were contradicting with their stream as happened to firqah Mu'tazili (al-Aczomi 1992 \& al-Sibacie 1985).

\subsection{The History Of The Rejection Of The Hadith In Modern Time}

After the 2nd century (AH), there was no longer heard about individual or groups who called out towards abandoning the sunnah (al-Sibaci 1985). At that time, Islam has to face with the movement of false hadith that began in the last quarter of the first century, though the seeds towards it has been started earlier (Fallatah 1981). Sunnah rejection in modern era began with the arrival of Western invaders who conquered Muslim countries.

\subsection{Judgement For Denying The Hadith}

According to Imam al-Shawkani (t.th.), convictions on the arguements towards the holy sunnah and its personal way in determining matters of legislation were already known in religion, none who contradict this matter but receive no reward for him even the slightest in Islam. Ibn Hazm (t.th.) viewed, a Muslim who believed the oneness of Allah could not refer to other than the Qur'an and the Sunnah of the Prophet S.A.W. when arguing. He also could not deny with what were in both. If he did that when he realized (qiam al-hujjah), he was a sinner. If he thought he could do it out of order and the duty to obey one of them, then he was a disbeliever without a doubt. According to him: If someone said: "We will not accept anything unless what we found in the Qur'an", then this person was considered as an infidel according to the consensus of the ummah. The acceptance of such view would negate the five obligation prayers except a rakaah between the sunset until the nightfall and another one at dawn.

A Muslim has no choice but to accept the Qur'an and the Sunnah as the primary source in life. One could not say that he was committed to the teachings of Islam if he rejected the hadith as an argument (al-A'zomi 1992). The absence of Sunnah reference will cause a lot of issues regarding faith, worship, jurisprudence and many other things which were excluded from the tenets of Islam. Thus, the form of Islam which was not perfect will appear, lack of everything, different from what have been brought by the Prophet S.A.W. The influences of the Sunnah were things that could not be denied. That was why Imam al-Auwza'i said: The Qur'an needs the Sunnah more than the Sunnah towards the Qur'an. Ibn Abd al-Bar said: The Sunnah states the rules in the Al-Qur'an and explains its meaning. Abu Yahya ibn Kathir said: The Sunnah is the judge of the Qur'an (al-Shawkani t.th.).

Sheikh Husain Makhluf, the former mufti of Egypt and the council member Ta'sis Rabitah al- 'Alam al-Islami Makkah in Akhbar al- 'Alam al-Islami dated 4 Muharram 1399H said: Whoever left the Sunnah of qauliah or ficliah that has remained from the Prophet S.A.W. in religious law, then he is an apostate (Husnan 1995).

\section{Research Methodology}

This study was conducted using a quantitative research design in which the researcher has distributed survey questionnaires to 1,200 public, private sectors and civil servants in the Klang Valley. According to Hohman (2006), quantitative method are originally developed in the natural sciences to study natural phenomena occur within a society. Therefore in this study 800 respondents involved to answer survey questionnaires related to anti-hadith phenomena in Malaysia. The survey questionnaires which have been distributed entailed three main constructs;

i. Demographic Background (Part A). This section contained questions on general information about demographic background of respondents.

ii. Muslims' Appreciation towards Religion (Part B). This section contained questions related to the Muslims' appreciation towards religion.

iii. Muslims' Response about the anti-Hadith Group (Part C). This section contained questions related to knowledge, feelings (perceptions and attitudes) and behaviour of Muslims against the anti-hadith. There are three methods which have been used by the researchers to distribute the survey questionnaires which were;

a. The researchers have distributed the survey questionnaires in governmental departments and private companies.

b. The survey questionnaires were distributed in these areas and the respondents were asked to return them to the author's address.

c. The researchers have sent the survey questionnaires via e-mail through contacts and further contacts will be extended to third parties, and so on.

The data analysis of this study was divided into two parts; descriptive analysis and inferential analysis (test of 
difference and correlation analysis). Both analyses were to answer the research questions and thus achieved the objectives of the study.

\section{Findings and Discussion}

The sample distribution was categorized into age, gender, status and race which have been shown in Table 1 as follows:

Table 1. Sample Profile according to age, gender, status and race

\begin{tabular}{llcc}
\hline \multicolumn{1}{c}{ Factor } & \multicolumn{1}{c}{ Categorized } & N & $\%$ \\
\hline Ages & 21-30 years & 316 & 39.5 \\
& 31-40 years & 251 & 31.4 \\
& 41-50 years & 179 & 22.4 \\
\multirow{3}{*}{ Gender } & 51-60 years & 54 & 6.8 \\
& Male & 400 & 50 \\
Status & Female & 400 & 50 \\
& Single & 239 & 29.9 \\
& Marriage & 555 & 69.4 \\
Race & Divorced & 6 & 0.8 \\
\hline Total & Malay & 800 & 100 \\
\hline
\end{tabular}

Based on Table 1 above, 316 respondents (39.5\%) were aged between 21-30 years, 251 respondents (31.4\%) were aged between 31-40 years, 179 respondents (22.4\%) were aged between 41-50 years and 54 respondents (6.8\%) were aged between 51-60 years. The number of all respondents was $800(100 \%)$. The table also shows that the number of male respondents was $400(50 \%)$ similar with the number of female respondents, which was $400(50 \%)$. In terms of status, the table shows that the number of respondents who were single was $239(29.9 \%)$ and the number of respondents who were married was $555(69.4 \%)$. The number of respondents who were divorced was $6(0.8 \%)$. The table also shows that $100 \%$ or 800 respondents of this research were among the Malay ethnic.

Table 2. Shows the item of pray in mosques

\begin{tabular}{ccccccccc}
\hline Item & NW & NB & $\mathbf{0}$ & $\mathbf{R}$ & VO & Mean & SP & Level \\
\hline Mosque & 21 & 196 & 394 & 155 & 34 & 2.98 & 0.845 & SR \\
& $(2.6 \%)$ & $(24.5 \%)$ & $(49.3 \%)$ & $(19.4 \%)$ & $(4.3 \%)$ & & & \\
\hline
\end{tabular}

Table 2 shows the item of pray in mosques, (mean $=2.98, \mathrm{sp}=0845$ ). It has been observed that $19.4 \%$ and $4.3 \%$ of respondents were regularly and very often went to mosques, $49.3 \%$ of them were occasionally and $24.5 \%$ and $2.6 \%$ of them were never have been and never went there. The table below shows in details the frequency of respondents by gender.

Tabel 3. The details the frequency of respondents by gender pray in mosque.

\begin{tabular}{llcccccc}
\hline & & NW & NB & O & R & VO & Total \\
\hline \multirow{2}{*}{ Gender } & Male & 2 & 48 & 187 & 131 & 32 & 400 \\
& Female & 19 & 148 & 207 & 24 & 2 & 400 \\
\hline Total & & 21 & 196 & 394 & 155 & 34 & 800 \\
\hline
\end{tabular}

Table 3 above shows that 163 male respondents (40.75\%) were frequently and very often went to the mosque for congregational prayers and the number for female respondents was $26(6.5 \%)$. The number of male respondents who occasionally went to the mosque was 187 (46.75\%) and 207 for female respondents (51.75\%). For men who never have been and never went to the mosque were 50 respondents (12.5\%). 
Table 3: Correlation between interest Muslim to study religious knowledge and influence of anti-hadis

\begin{tabular}{|c|c|c|c|}
\hline Correlation & $\mathbf{R}$ & Sig.P & Level \\
\hline 'Attend for lectures at the mosque' * the influence of the anti-hadith & $-0.162^{\star \star}$ & 0.000 & $\mathrm{~L}$ \\
\hline Attend Talks * the influence of the anti-hadith & $-0.126^{\star *}$ & 0.000 & $\mathrm{~L}$ \\
\hline 'Discuss religious issues' * the influence of the anti-hadith & $-0.178^{\star *}$ & 0.000 & $\mathrm{~L}$ \\
\hline
\end{tabular}

Table 4 above shows that there was a significant correlation at a low level on all items which were 'Attend for lectures at the mosque' ( $r=-0.162, p<0.01)$, 'Attend talks' $(r=-0.126, p<0.01)$ 'Discuss religious issues' $(r=-0.178, p<0.01)$. Overall, the relationship between the interests to study religious knowledge with the influence of the anti-hadith was in a low level.

Table 5. Correlation between 'congregation in the mosque' and influence of anti-hadis

\begin{tabular}{lccc}
\hline Correlation & $\mathbf{R}$ & Sig.P & Level \\
\hline 'congregation in the mosque' * influence of anti-hadis & $-0.108^{\star *}$ & 0.002 & $\mathrm{~L}$ \\
\hline
\end{tabular}

Table 5 above shows that there was a significant correlation at a low level in the 'congregation in the mosque' $(r=-0.108$, $p<0.01)$ '. Overall, the relationship between the practices of Muslims with the effect of the anti-hadith was in a low level $(r$ $=-0.221, p<0.01)$.

The detailed analysis of the findings have shown that those who liked to present themselves in mosques were safe from the anti-hadith influences. This illustrated that the religious studies in mosques have managed to keep the faith of Muslims from misguided. In terms of practicing Islamic teachings, Muslims were less potential to be influenced by the anti-hadith than those who did not go to the mosques.

\section{Concluding Remarks}

Muslims who have discussions on religious matters, presented themselves to the mosque for religious study and followed the lectures were the safest from being influenced by the anti-hadith ideologies. Given the religious education in the mosques were among the main factors which could save Muslims from the influence of the anti-hadith group, it is recommended that all parties should enhance and diversify religious lectures. Campaigns for Muslims to go to the mosques must be held immediately so that the lectures could be attended by many people. Those who liked to discuss religious matters were also in a safe zone from the influence of the anti-hadith group. Therefore, it is suggested that Islamic scholars should have discussions especially on current issues at the end of their talks or lectures, attended by public people.

\section{References}

\section{Al-Qur'an}

al-Nawawi, Ibn Neural Araz. H.Th. Kitab al-majmuc syarh al-muhazzab. Jeddah: Maktabah al-Irshad. al-Nawawi, Ibn Neural Araz. H.Th. Tahzib al-Asma 'wa al-lughat. Beirut: Dar al-Pole al-cllmiyyah. al-Firuzabadi, Majd al-Din Muhammad ibn Yackub. 1407H / 1987. al-Qamus al-Muhith, Beirut: al-Risala Muassasah al-Shawkani, Muhammad ibn Cali. H.Th. Irshad al-Fuhul A Verification Ila al-rights cilmi min al-motion. Cairo: Dar al-polar. al-Aczomi, Muhammad Mustafa. 1413H / 1992. Dirasat fi al-hadith al-Nabawi wa tadwinihi date. Beirut: al-Maktab al-Islami.

Ahmad, Ahmad ibn Hanbal. 1419H / 1998. Musnad. Riyard: Bait al-Afkar al-Dauliyyah. Ahmad Husnan. 1416H / 1995. Inkaru movement al-Sunnah and the answer. Ed. 3rd. Jakarta: Media propaganda

Baheis, the Islamic Affairs Division of the Prime Minister. 1995. Explanation The notion Antihadis. Kuala Lumpur: Islamic Affairs Division of the Prime Minister.

Dictionary. 2002. Ed. 3rd. Kuala Lumpur: Dewan Bahasa dan Pustaka.

Khalil al-Jur. Larus 1987. mucjam al-al-al-hadith Carabi. Paris: Maktabah Larus.

Ibn Manzur, Mukram Jamaluddin Muhammad ibn al-Ansari. H.Th. Lisan al-carab.

t.tpt .: Muassasah Misriah al-al-al-Ta'lif disgraced lil wa al-Anba 'wa al-Nasr Ibn Hazm, al-Hafiz Abu Muhammad Hazmi Cali ibn alAndalusi al-Zahiri. H.Th. al-Ihkam fi al-Ahkam motion. Egypt: Matbacah al-Imam.

Ibn Hazm, Cali ibn Ahmad. H.Th. al-muhalla. Beirut: Dar al-Jail.

Hafiz Firdaus Abdullah. 2002. 20 Arguments group antihadis and answers. Johor Bahru: Freeshipping.

Sharah Sahih Muslim Imam Nawawi, The Book of Knowledge, Maktabah al-Mu'aiyad, Riyard, CTK. 1, 1994 / 1414H jzk. 16, p. 443. 
Al-Khatib, Abu Bakr Ahmad ibn Ali al-Khatib al-Baghdadi, Kitab al-Kifaya fi al-ilmi riwayah, Dar al-Pole al-Ilmiyyah, Beirut, No CTK. 1988 / 1409H, about takhsis public li al-Sunan al-Qur'an muhkam, hlm.15 and al-Hakim, Abu Abdullah Muhammad ibn Abdullah alHakim al-Nisaburi, al-Mustadrak ala al-Saheehayn, Dar al-Pole al-Ilmiyyah, Beirut, Ed. 1, 1990 / 1411H, jzk.1, hlm.192.Sahih Muslim Sharah Imam Nawawi, Kitab IImu, Maktabah al-Muayyid, Riyard, ctk. 1, 1994/1414H jzk. 16, hIm. 443.

Al-Khatib, Abu Bakar Ahmad ibn Ali al-Khatib al-Baghdadi, Kitab al-kifayah fi ilmi al-riwayah, Dar al-Kutub al-Ilmiyyah, Beirut, tiada ctk. 1988/1409H, bab takhsis al-sunan li umum muhkam al-Qur'an, hlm.15 dan al-Hakim, Abu Abdullah Muhammad ibn Abdullah alHakim al-Nisaburi, al-Mustadrak ala al-sahihain, Dar al-Kutub al-Imiyyah, Beirut, Ed. Ke-1, 1990/1411H, jzk.1, hlm.192.

Sahih Muslim, Maktabah al-Muayyid, Riyard, ctk. 1, 1994/1414H, kitab al-Zakat (5/12), bab zikr al-Khawarij wa sifatihim (48/47), jzk. 7, hlm.162.

Al-Khatib, Abu Bakr Ahmad ibn Ali al-Khatib al-Baghdadi, Kitab al-Kifaya fi al-ilmi riwayah, Dar al-Pole al-Ilmiyyah, Beirut, No CTK. 1988 I 1409H, about takhsis public li al-Sunan al-Qur'an muhkam, hlm.15 and al-Hakim, Abu Abdullah Muhammad ibn Abdullah alHakim al-Nisaburi, al-Mustadrak ala al-Saheehayn, Dar al-Pole al-Ilmiyyah, Beirut, Ed. 1, 1990 / 1411H, jzk.1, hlm.192.

Al-Khatib, Abu Bakr Ahmad ibn Ali al-Khatib al-Baghdadi, Kitab al-Kifaya fi al-ilmi riwayah, Dar al-Pole al-Ilmiyyah, Beirut, No CTK. 1988 / 1409H, about takhsis public li al-Sunan al-Qur'an muhkam, hlm.15 and al-Hakim, Abu Abdullah Muhammad ibn Abdullah alHakim al-Nisaburi, al-Mustadrak ala al-Saheehayn, Dar al-Pole al-IImiyyah, Beirut, Ed. 1, 1990 / 1411H, jzk.1, hlm.192.

Al-Bukhari, Sahih with Fath al-Bari, Dar al-Rayyan, Cairo, ctk.1, (1987 / 1407H), Kitab al-Libas (77), about al-Mutanammisat (84), jzk. 10, p. 390.

Muslim, Sahih along Sharah Sahih Muslim, al-Mu'aiyad Maktabah, Riyard, CTK. 1, (1994 / 1414H), Kitab al-Libas, about tahrim ficel alwasilah wa al-mustausilah, jzk. 14, hlm.331.

Al-Khatib al-Baghdadi, al-Kifaya riwayah fi al-IImi, p. 16.

Habeeb Rahman Ibramsa. (2004). Pemikiran Antihadis Dan Perkembangan Semasa. Kertas kerja Seminar Hadis:Cabaran Dan Masa Depan. Anjuran UKM dan KUIS. Bangi, Selangor, 13 Mac.[Translate: Thought Antihadis And Current Developments.The paper reported Seminar: Challenges and the Future. Organised by UKM and KUIS. Bangi, Selangor, 13 March.]

Muhaidi Hj Mustaffa Al Hafiz, Mohd Al'Ikhsan Ghazali, Siti Salwa Md. Sawari. (2015a). Eksplorasi Hubungan Hafazan Al-Quran Dan Kecemerlangan Para Pelajar Maahad Tahfiz Al-Quran Wal Qiraat Pulai Chondong. International Seminar on Educational Issues 2015. Selangor International Islamic College University. [Transform: Explore Relationship memorizing Al-Quran And Excellence Students Tahfiz Institution Al-Quran Wal Qiraat Pulai Chondong. International Seminar on Educational Issues 2015 Selangor International Islamic University College ]

Muhaidi Hj Mustaffa Al Hafiz, Mohd Al'Ikhsan Ghazali, Siti Salwa Md. Sawari. (2015b). Transformasi Pendidikan Hafazan Al Quran Dari Zaman Awal Islam Hingga Kini. International Seminar on Educational Issues 2015. Selangor International Islamic College University.[Translate: Transforming Education memorizing the Koran From Early Islamic Until now. International Seminar on Educational Issues 2015 Selangor International Islamic University College.].

Al Hafiz, M., Yusof, M., Ghazali, M., \& Sawari, S. (2016). Descriptive Qualitative Teaching Method of Memorization in The Institution of Tahfiz Al-Quran Wal Qiraat Pulai Condong and the Students' Level of Academic Excellence. Mediterranean Journal Of Social Sciences, 7(1 S1), 79. Retrieved from http://www.mcser.org/journal/index.php/mjss/article/view/8721/8379

Al Hafiz, M., Yusof, M., Ghazali, M., \& Md. Sawari, S. (2016). Historiography of Quranic Memorization from the Early Years of Islam until Today. Mediterranean Journal Of Social Sciences, 7(1 S1), 279. Retrieved from http://www.mcser.org/journal/index.php/ mjss/article/view/8747

al-Sibaci, Mustaffa al-Sibaci. 1405H/1985. al-Sunnah wa makanatuha fi al-tasric al-islami. Ed. ke-4. Beirut: al-Maktab al-Islami.

Hohman. U., (2006). Quantitative Methods in Education Research. Reterived 23/7/2015 from http://www.edu.plymouth.ac.uk/resined/ quantitative/quanthme.htm

al-Aczomi, Muhammad Mustafa. 1413H/1992. Dirasat fi al-hadith al-nabawi wa tarikh tadwinihi. Beirut: al-Maktab al-Islami.

Fallatah, cUmar ibn Hassan. 1401H/1981. al-Wadc fi al-hadith. Damsyiq: Maktabah al-Ghazali.

Siti Salwa Md. Sawari, Mohd Al'ikhsan Ghazali, Mohamad Muntaha Salleh. (2015). Penyebaran Fahaman Anti Hadis Dan Kesannya Terhadap Akhlak. National Research Seminar. Universiti Sultan Idris. 4 April 2015. [Translate: Ideology Dissemination Anti Hadith And Its Impact morals. National Research Seminar. Sultan Idris University. ]DOI: 10.13140/RG.2.1.4010.1281.

Ghazali, M., Md. Sawari, S., \& Yusuf, M. (2015). The Severity of Anti Hadith Groups (AHG) Thought: Solutions, Challenges and Barriers. Mediterranean Journal Of Social Sciences, 6(3 S2), 127. Retrieved from http://www.mcser.org/journal/index.php/mjss/article/ view/6473/6203<http://www.mcser.org/journal/index.php/mjss/article/view/6473/6203>. Date accessed: 23 Jan. 2016.

Ghazali, M. A., Sawari, S. S. M., .2014. The Influence of anti Hadith Group (GAH) Thinking on the Muslim Ummah: A Special Study in the Klang Valley. Al-Bayan: Journal of Qur'an an Hadith Studies 12 (1), 75-86, 17 July 2014, Retrieved from http://books andjournals.brillonline.com/content/journals/22321969/12/1 